УДК: 551.242:004.4, https://doi.org/10.37878/2708-0080/2021-2.04

\title{
УГЛЕВОДОРОДНАЯ СИСТЕМА НАДСОЛЕВОГО КОМПЛЕКСА ПРИКАСПИЙСКОЙ ВПАДИНЫ (НА ПРИМЕРЕ ТЕНГИЗ-КАРАСОР)
}

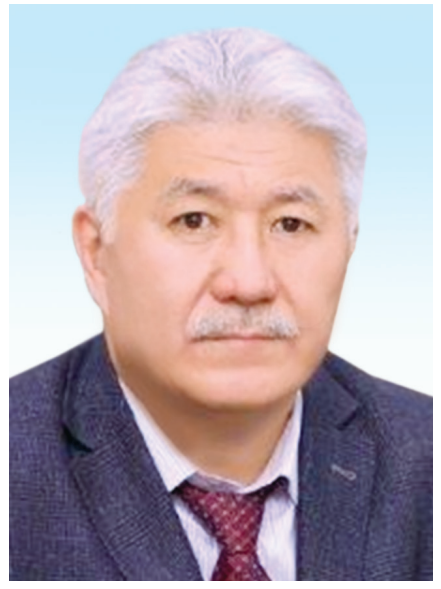

К.А. АДИЛБЕКОВ ${ }^{1}$, заместитель генерального директора по геологоразведке

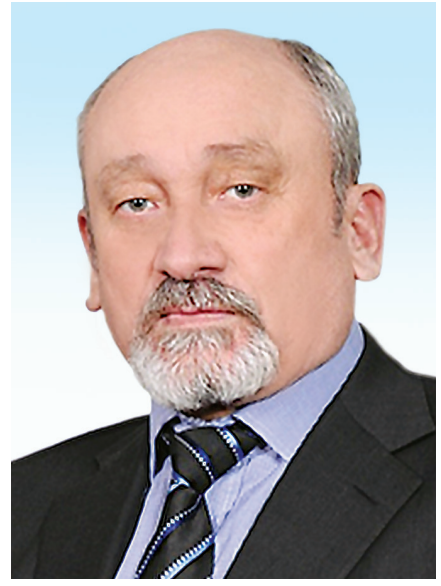

Н.Г. МАТЛОШИНСКИЙ²*, технический директор, кандидат геол.-мин. наук, https://orcid.org/0000-00018028-782X

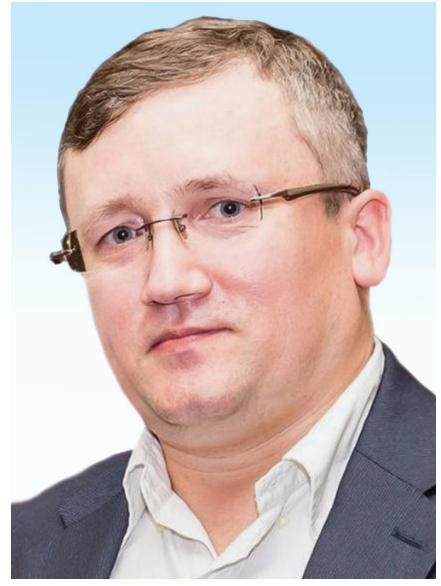

Р.Н. МАТЛОШИНСКИЙ², главный специалист по геоинформационным системам, кандидат биологических наук, https://orcid.org/0000-00032046-6695

${ }^{1}$ АО «ЭМБАМУНАЙГАЗ» Республика Казахстан, 060002, г. Атырау, ул. Валиханова 1

${ }^{2}$ TOO «RESERVOIR EVALUATION SERVICES»

Республика Казахстан, 050044, г. Алматы, ул. Ахмедиярова, 24

Вопросы миграции нефти из подсолевых отложений в надсолевые через бессолевые мульды вызывают все больший интерес в связи с прогнозом залежей в надсолевом комплексе. Характер и особенности миграции УВ при этом изучены в малой степени. Лучше всего изучение этого вопроса проводить на материалах надсолевых залежей нефти и газа, расположенных над подсолевыми месторождениями. В работе рассматривается возможность перетока нефти месторождения Тенгиз в надсолевое (нижний мел) нефртяное месторождение Карасор Западный, расположенное над юго-западной периферией Тенгизского месторождения.

КЛЮЧЕВЫЕ СЛОВА: свойства нефти, миграция нефти, перетоки, бессолевые мульды, сейсмические разрезы, пути миграции, сейсмические атрибуты.

\section{КАСПИЙ МАНЫ ОЙПАТЫНЫН ТҰЗ YСТI КЕШЕНIНIҢ КӨМIРСУТЕК ЖҮЙЕСІ (ТЕНІЗ-ҚАРАСОР МЫСАЛЫНДА)}

\footnotetext{
* Автор для переписки. E-mail: nmatloshinskiy@gmail.com
} 
К.А. АДИЛБЕКОВ ${ }^{1}$, «ЭмбаМунайГаз» АҚ, геологиялық барлау жөніндегі бас директордың орынбасары

Н.Г. МАТЛОШИнСКИЙ2*, «RES» ЖШС, техникалық директор, https://orcid.org/0000-0001-8028-782X;

P.H. МАТЛОШИНСКИЙ², «RES» ЖШС, КТ жетекші маманы, https://orcid.org/0000-0003-2046-6695

\author{
${ }^{1}$ «МББАМУНАЙГАЗ» АҚ \\ Қазақстан Республикасы, 060002, Атырау қ., Уалиханов к-сі, 1 \\ ${ }^{2}$ ЖШC «RESERVOIR EVALUATION SERVICES» \\ Қазақстан Республикасы, 050044, Алматы қ. Ахмедияров к-сі, 24
}

Тұздан кейінгі шұңқырлар арқылы мұнайдың тұзды шөгінділерден тұздан кейінгі шөгінділерге көшуі мәселелері қызығушылықты арттырады. Сонымен бірге ХС миграциясының табиғаты мен ерекшеліктері өте аз дәрежеде зерттелді. Бұл мәселені тұзды қабаттардың үстінде орналасқан мұнай мен газдың тұздан кейінгі шөгінділері материалдары бойынша зерттеу жақсы. Мақалада Теңіз кен орнынан Теңіз кен орнының оңтүстік-батыс перифрериясының үстінде орналасқан, тұздан кейінгі (К1) мұнай кен орнына Қарасор батысына мұнай ағу мүмкіндізі қарастырылған.

ТҮЙІн СөзДЕР: мұнай қасиеттері, мұнайдың миграциясы, көлденең ағындар, тұзсыз науалар, сейсмикалық учаскелер, миграция жолдары, сейсмикалық атрибуттар.

\title{
HYDROCARBON SYSTEM OF THE POST-SALT COMPLEX OF THE PRECASPIAN DEPRESSION (ON THE EXAMPLE OF TENGIZ-KARASOR)
}

K.A. ADILBEKOV'1, Exploration deputy Director General;

N.G. MATLOSHINSKIY²*, RES LLP, Technical Director, https://orcid.org/0000-0001-8028-782X;

R.N. MATLOSHINSKIY², RES LLP, Leading specialist on CT, https://orcid.org/0000-0003-2046-6695

\author{
${ }^{1}$ «EMBAMUNAIGAS» JSC \\ 1, Valikhanov st., Atyrau, 060002, Republic of Kazakhstan, \\ ${ }^{2}$ «RESERVOIR EVALUATION SERVICES» LLP \\ 24, Akhmediyarov st., Almaty, 050044, Republic of Kazakhstan
}

The issues of oil migration from pre-salt deposits to post-salt deposits through salt-free troughs are of increasing interest in connection with the forecast of deposits in the post-salt complex. At the same time, the nature and features of HC migration have been studied to a small extent. It is best to study this issue on the materials of post-salt deposits of oil and gas located above the subsalt deposits. The paper considers the possibility of oil flow from the Tengiz field to the post-salt (Lower Cretaceous) oil field Karasor West, located above the southwestern periphery of the Tengiz field.

KEYWORDS: oil properties, oil migration, crossflows, salt-free troughs, seismic sections, migration routes, seismic attributes.

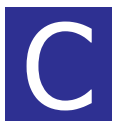

читается общепринятым, что нефть надсолевого комплекса Прикаспийской впадины в основном имеет подсолевое происхождение и мигрировала из подсолевых нефтегазоматеринских отложений через бессолевые окна в глубоких мульдах $[1,3,4-8]$. Это положение нашло реальное подтверждение в последние годы, благодаря изучению биомаркеров [5,9]. Само положение о генерации надсолевой нефти подсолевыми отложениями, кроме изучения биомаркеров, прямыми замерами не доказано из-за недоступности материала (большие глубины) и базируется на моделировании по результатам изучения пород в прибортовых зонах 
$[1,8]$. В немалой степени это представление появилось в противовес представлению о собственном генерационном потенциале надсолевого комплекса, который не нашел подтверждения в результатах изучения палеотемператур и степени преобразования ОВ.

Время от времени идея генерации УВ надсолевым комплексом возрождается и очаги генерации переносятся в глубокие мульды. Иногда поводы, по которым это делается - нефть месторождений Аккудук, Кисимбай, в которой наряду с проявлениями генезиса из карбонатных отложений, также есть признаки генезиса терригенными нефтематеринскими отложениями [9], смотрятся не очень убедительными. Не обязательно приписывать терригенную составляющую надсолевому комплексу отложений, сложенному здесь красноцветными породами пермотриаса, когда в подсолевых отложениях этой части впадины доминируют мощные терригенные толщи.

Для успешных поисков месторождений нефти и газа очень важно научиться выделять мульды, через которые могла происходить миграция нефти из подсолевых отложений и также уметь распознавать мульды, которые сами могли генерировать УВ, если это действительно имело место. В последнем случае можно было бы проводить исследования стадии преобразования ОВ нефтематеринских отложений, типа УВ, которые они могли генерировать и времени этого процесса, чтобы иметь четкое понимание, как это могло происходить. К сожалению, в практике ГРР пока такой подход широко не используется, и поиски по-прежнему ведутся, ориентируясь на ловушки, без изучения всей цепочки УВ системы: генерация, миграция, аккумуляция и сохранение.

Вместе с тем, если есть представление о том, что нефть из подсолевых отложений мигрировала в надсолевые, то первое, что нужно в этом плане изучать, так это нефти надсолевых залежей, развитых над известными подсолевыми месторождениями и возможные пути их миграции. В настоящей работе рассматривается соотношение залежей нефти месторождения Тенгиз и развитого над его западной периферией надсолевого (нижний мел) месторождения Карасор Западный. Такое рассмотрение в плане решения вопроса о природе нефти ценно в первую очередь тем, что месторождение Тенгиз, несомненно, представляет собой вместилище огромного количества нефти, сформированной во внутренней части впадины ее нефтематеринскими отложениями. Иными словами, нефть подсолевого Тенгиза представляет собой типичную нефть, которую может генерировать Прикаспийская впадина.

Подсолевые отложения внутренней части Прикаспийской впадины представлены комплексом карбонатных глубоководных и терригенных, снесенных с окружения, осадков, среди которых выделяются части разреза, богатые сапропелевой органикой, относимые к нефте- или газоматеринским, в зависимости от глубины погружения. Традиционно основным генерирующим комплексом считаются отложения среднего девона. В то же время, на огромных пространствах впадины развиты депрессионные отложения, по меньшей мере, трех карбонатных комплексов: верхнедевонско-турнейского, визейско-башкирского и нижнемосковско-артинского, которые по всем своим признакам являются идеальными кандидатами в нефтегазогенерирующие породы, собственно, то, что в западной литературе называется «condensed section».

Локальные органогенные постройки, одним из лучших представителей которых в Прикаспии по праву считается Тенгизская, располагаясь в поле депрессионных отложений и непосредственно над среднедевонскими нефтематеринскими поро- 
дами как высокоемкие резервуары вбирали в себя все, что генерирующие толщи смогли произвести. Судя по аномально высокому давлению в нефтяной залежи месторождения, в него вместилось больше УВ, чем позволял изначальный объем. Очень важным моментом является то, что по резервуару месторождения нет никакой дифференциации нефти, в общем она достаточно однородна [2] и на это, похоже, поработала конвекция, хотя и замедленная, но неизбежно происходящая в резервуape, так как нефть, имеющая более высокую температуру внизу, будет стремиться перетечь вверх и наоборот.

Таким образом, тенгизская нефть представляет собой естественную представительную смесь нефти подсолевого генерационного комплекса Прикаспийской впа-

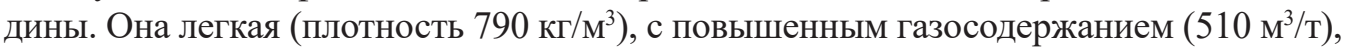
находится под аномальным пластовым давлением с коэффициентом аномальности $1,8\left(\mathrm{P}_{\text {пл }}=82,4\right.$ МПа на отметке - 4500м) при давлении насыщения 25,3 МПа. Растворенный в нефти газ содержит порядка 13\% сероводорода и 2,5\% двуокиси углерода. Сама нефть характеризуется как легкая, сернистая, малосмолистая, малопарафинистая. Температура застывания колеблется от -5 до $-35^{0} \mathrm{C}$, при среднем $-23^{0} \mathrm{C}$. По фракционному составу нефть относится к особо легким, имея общий выход светлых фракций, выкипающих до температуры $300^{\circ} \mathrm{C}$, - 70\% об., бензиновых фракций, выкипающих до температуры $200^{\circ} \mathrm{C}-44 \%$ об. [2,10].

История освоения месторождения Карасор Западный, расположенного над юго-западной периферией Тенгиза, растянулась почти на 60 лет, но к началу его освоения все еще практически не приступили. Структура Карасор выявлена в 1959 году сейсмическими работами треста «Казахстаннефтегеофизика». Уже через четыре года в 1963 году здесь было пробурено 4 скважины (Г-1-4), из которых только в скв. Г-2 был получен приток нефти из апт-неокомских отложений (инт. 1189-1192 м). Наряду со структурно-поисковым бурением (до 500 м), в последующие два года было пробурено еще 4 скв. (Г-8, Г-9, Г-14 и Г-18), из которых только в скв. Г-9 был вскрыт нефтяной горизонт в отложениях апта. Из-за низкой эффективности поисковые работы были приостановлены.

В 1974 - 1978 гг. трестом «Саратовнефтегеофизика» на данной площади были проведены детальные сейсмические работы МОГТ 2Д. Полученные структурные построения (горизонты III, V, VI, П1), среди прочего, позволили продолжить работы в пределах месторождения. По их результатам в 1981 г. силами Балыкшинского УРБ объединения «Эмбанефть» были пробурены скв. 1, 10, 11, 12, 13 с проектным горизонтом - кунгур. Из всего вскрытого разреза в пяти скважинах только в скв. 1 по ГИС был выявлен нефтяной пласт в нижнеальбских отложениях. Всего, таким образом, на площади Карасор Зап. пробурено тринадцать глубоких поисково-разведочных скважин и выявлено три нефтяных горизонта в трех нижнемеловых отложениях.

В 1989 - 1992 гг. СП «Тенгизшевройл» проведены сейсмические исследования МОГТ 3Д. В 2013 г и 2018-19 гг была проведена переобработка и переинтерпретация сейсморазведочных данных МОГТ 3Д на блоке Каратон-Саркамыс (TOO «PGSK»). В соответствии с полученными результатами был составлен проект разведочных работ в данном районе, предусматривающий расконсервацию и испытание четырех ранее пробуренных скважин с дальнейшими геолого-промысловыми исследованиями. 
По результатам расконсервации трех скважин 1, Г-2 и Г-9 и проведенного в них испытания были получены достаточно хорошие притоки качественной нефти с дебитами на штуцерах 9-11 мм от 84 до 136 м³/сут по каждому из трех горизонтов. В 2019 г. подготовлен «Отчет по оперативному подсчету запасов УВС месторождения Карасор Западный» (Протокол ГКЗ РК №2077-19-П от 15.08.2019 г). Запасы нефти по категории С1 составляют 1191/356 тыс. т (геологические/извлекаемые), по категории С2 - 6302/1418 тыс. т, соответственно.

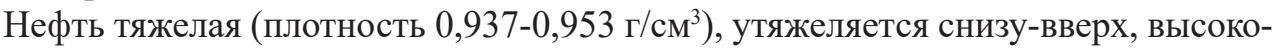
сернистая $(2,2-2,5 \%)$, смолистая $(19,6 \%)$, парафиновая $(3,3 \%)$ в альбском горизонте и малопарафиновая $(0,1-0,15 \%)$ в аптском и неокомском горизонтах. Температура застывания нефти минус $42^{\circ} \mathrm{C}$. Кинематической вязкость - при $20^{\circ} \mathrm{C}$ равна $260,1-380,7 \mathrm{Mм}^{2} / \mathrm{c}$, при $50^{\circ} \mathrm{C}-44,6-55,2 \mathrm{Mм}^{2} / \mathrm{c}$. Выход светлых фракций, выкипающих при $300^{\circ} \mathrm{C}$, составляет $20-21 \%$; выход бензиновых фракций, выкипающих до $240{ }^{0} \mathrm{C},-5 \%$. Содержание растворенного газа принято равным $34,1 \mathrm{~m} 3 / \mathrm{T}$ по результатам двух глубинных проб из альбского горизонта. В аптском и неокомском горизонтах в трех пробах было зафиксировано низкое содержание газа (6,6-10,1 м³/т), что было объяснено некачественным отбором проб. Средняя плотность пластовой

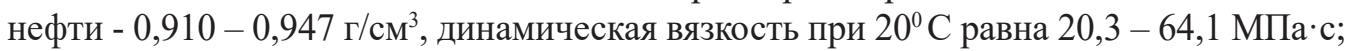
давление насыщения составило 10,5 Мпа при пластовом давлении 11,6-13,1 МПа и пластовой температуре $42,2-45,4^{\circ} \mathrm{C}$. Объемный коэффициент равен 1,06 при усадке $5,62 \%$, пересчетный коэффициент соответственно равен 0,943 .

Месторождение Карасор Западный, как уже было сказано, располагается над западной частью гигантского подсолевого месторождения Тенгиз. Однако, если допустить переток нефти из месторождения Тенгиз, то возникает вопрос надежности покрышки Тенгизского месторождения, его сохранности при практически предельном заполнении ловушки (ВНК - 5450 м). Ответом на него может быть допущение, что относительно небольшие количества нефти из месторождения Тенгиз перетекали в вышележащие надсолевые отложения при срабатывании всей сложной системы его покрышек как предохранительного клапана, когда давление внутри резервуара поднималось до определенного предела. Это справедливо в том плане, что пластовое давление на Тенгизе характеризуется почти двукратным превышением гидростатического (Каном $=1,8)$.

Сравнение нефти месторождения Карасор Западный и нефти месторождения Тенгиз (таблица 1) показывает, что, в принципе, первая могла быть образована из последней за счет дегазации и потери легких фракций на путях миграции в мощной терригенной толще. Такая дегазация, в первую очередь, приводила бы к тому, что газ из нефти выделялся бы на глубине начиная от - 2500 м (Р нас. 25,3 МПа). Иными словами, ниже глубины 2,5 км вторичные залежи должны быть нефтяными, а выше ее в нижней части преимущественно газовыми (газоконденсатными) и только в самых верхних горизонтах, куда вытеснена дегазированная, потерявшая легкие фракции нефть, состав нефти может быть таким, как на месторождении Карасор Западный.

Интересным в этом плане выглядит то, что нефть самой верхней альбской залежи выглядит более свежей с повышенным газосодержанием и высоким со- 


\section{ГЕОЛОГИЯ}

Таблица 1 - Сопоставление свойств нефти месторождений Тенгиз и Карасор Западный

\begin{tabular}{|c|c|c|c|}
\hline \multirow{2}{*}{ Свойства } & \multirow{2}{*}{$\begin{array}{c}\text { Единица } \\
\text { измерения }\end{array}$} & \multicolumn{2}{|c|}{ Месторождения } \\
\hline & & Тенгиз & Kарасор Зап. \\
\hline Плотность & $\mathrm{K} \Gamma / \mathrm{M}^{3}$ & 790 & 945 \\
\hline Газосодержание & $\mathrm{M}^{3} / \mathrm{T}$ & 500 & 34.1 \\
\hline Пластовое давление & Mpa & 82 & 13.1 \\
\hline Давление насыщения & МПа & 25.3 & 10.5 \\
\hline Выход фракций до 200 C & $\%$ об & 44 & 5 \\
\hline Выход фракций до $300^{\circ} \mathrm{C}$ & $\%$ ०б & 70 & 20 \\
\hline $\mathrm{H}_{2} \mathrm{~S}$ в растворенном газе & $\%$ об & 13 & 0 \\
\hline Cepa & \%мacc & 0.95 & 2.5 \\
\hline Парафин & $\%$ мacc & 3.9 & $0,15-3,3$ \\
\hline Смолы & $\%$ мaсc & 1.1 & 19,6 \\
\hline
\end{tabular}

держанием парафина. Возможно, различие в газонасыщении не связано с качеством проб, а отражает реальные процессы формирования залежей с постепенным заполнением ловушек, в ходе которого самая верхняя ловушка была заполнена после заполнения нижних.

Для изучения вопросов миграции нефти из подсолевых отложений был проведен анализ строения соленосной толщи, особенно в самых глубоких мульдах. В результате были выявлены участки мульд, где соль практически полностью выжата. На рисунке 1 приведена структурная карта по кровле аптского продуктивного горизонта, на которой показаны контуры трех близлежащих бессолевых мульд и вероятные пути миграции нефти из них, определяемые строением самих мульд. На врезке к рисунку дана структурная карта кровли соли с положением выявленных бессолевых мульд (обработка и интерпретация TOO «RES», 2020 г.).

Очевидно, что не каждую глубокую мульду можно сразу относить к мульдам, через которые шла миграция. Для уверенного суждения об этом необходимо увидеть отражение такой возможности в сейсмике. На рисунке 2 представлен горизонтальный срез по уровню 2500 мсек через всю переобработанную в TOO «RES» Карасорскую часть куба. Здесь хорошо можно видеть контур месторождения Тенгиз и положение пробуренных скважин на Карасоре Западном. Разрез по линии 2655 приведен на рисунке 3, на котором хорошо видно отражение бессолевой мульды в подсолевом разрезе, что, скорее всего, вызвано характерным обезвоживанием верхней части подсолевого терригенного пермского разреза при контакте с бессолевой мульдой. Уплотнение глин при этом привело к увеличению скорости в пачке и, как следствие, к небольшому скоростному подскоку на сейсмическом разрезе.

Заполнение меловых залежей месторождения Карасор Западный могло быть обеспечено из двух прилегающих небольших мульд (рисунок 1), однако, отражения 


\section{ГЕОЛОГИЯ}

северной мульды в амплитудном срезе на рисунке 2 особенно не видно, возможно, из-за ее положения над краевой частью месторождения Тенгиз. Нужно иметь в виду, что именно эта мульда могла обеспечить заполнение самой восточной ловушки месторождения. Пути миграции УВ из мульды в надсолевые ловушки показаны на линии D-D’ (рисунок 4), которая соединяет бессолевую мульду последовательно практически со всеми карасорскими скважинами.

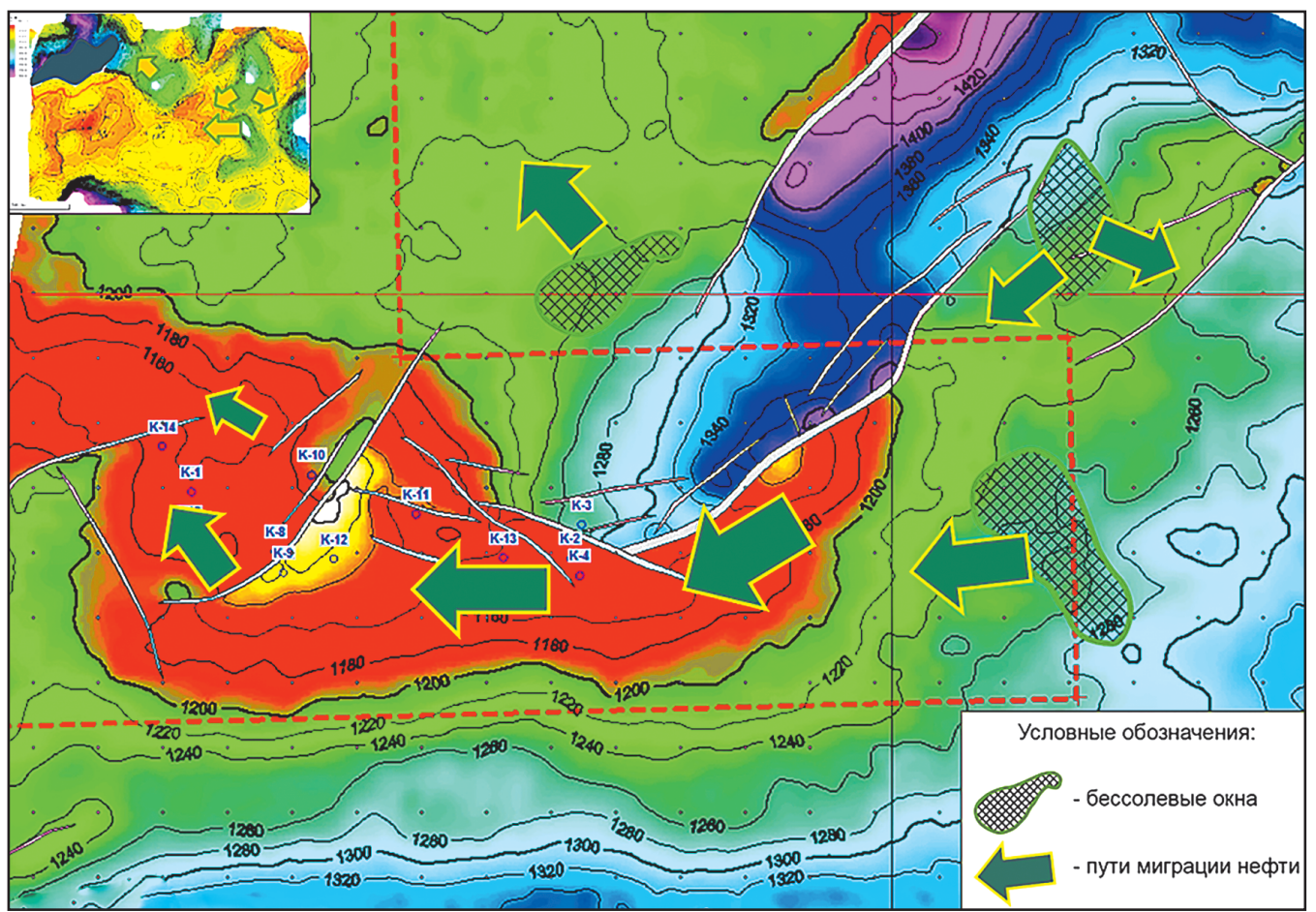

Рисунок 1 - Карасор Западный. Положение бессолевых мульд относительно структурного плана месторождения (карта по кровле альбского горизонта) и вероятные пути миграции.

На врезке карта кровли соли (обработка и интерпретация TOO «RES», 2020).

Из соотношения глубины и давления насыщения тенгизской нефти следует, что до нарушения УВ смесь должна была доходить в однородном нефтяном составе, а уже в самом начале движения по нарушениям разделяться на две фазы жидкую и газообразную. В нижнюю часть надсолевых отложений УВ поступали в виде жидкой фазы, которая могла заполнять ловушки в нижней части разреза, по мере перемещения УВ выше (критической является глубина в 2,5 км) система должна разделяться на газ с конденсатом и нефть. При заполнении ловушек газ вытеснял нефть за их пределы, вынуждая её мигрировать в выше расположенные ловушки. Таким образом, мы имеем ситуацию, когда внизу (ниже 2,5 км) могут быть залежи легкой нефти, с высоким газосодержанием, а вверху $(1,1-1,2$ км) залегают дегазированные тяжелые нефти с высоким содержанием серы, что для надсолевых отложений не очень характерно. В промежутке между ними должны размещаться залежи газа, возможно, с разным содержанием конденсата, которые должны были бы проявляться в сейсмических данных наличием ярких амплитуд.

НЕФТЬ И ГАЗ 20212 (122) 


\section{ГЕОЛОГИЯ}

Анализ сейсмических материалов на всем пространстве от бессолевого окна до залежи тяжелой нефти показывает, что кандидатов на залежи газа здесь не прослеживается (рисунки 3, 4). Тем не менее, для более детального изучения данного вопроса, в программе PaleoScan был протрассирован пласт из района ниже скв. К-13 на рисунке 4, в котором резко по восстанию уменьшается яркость отражения, что может фиксировать наличие литологически экранированной ловушки, заполненной газом.

Однако анализ сейсмических материалов показал, что пласт не характеризуется сплошным и выдержанным развитием, а имеет пятнистое нерегулярное распространение.

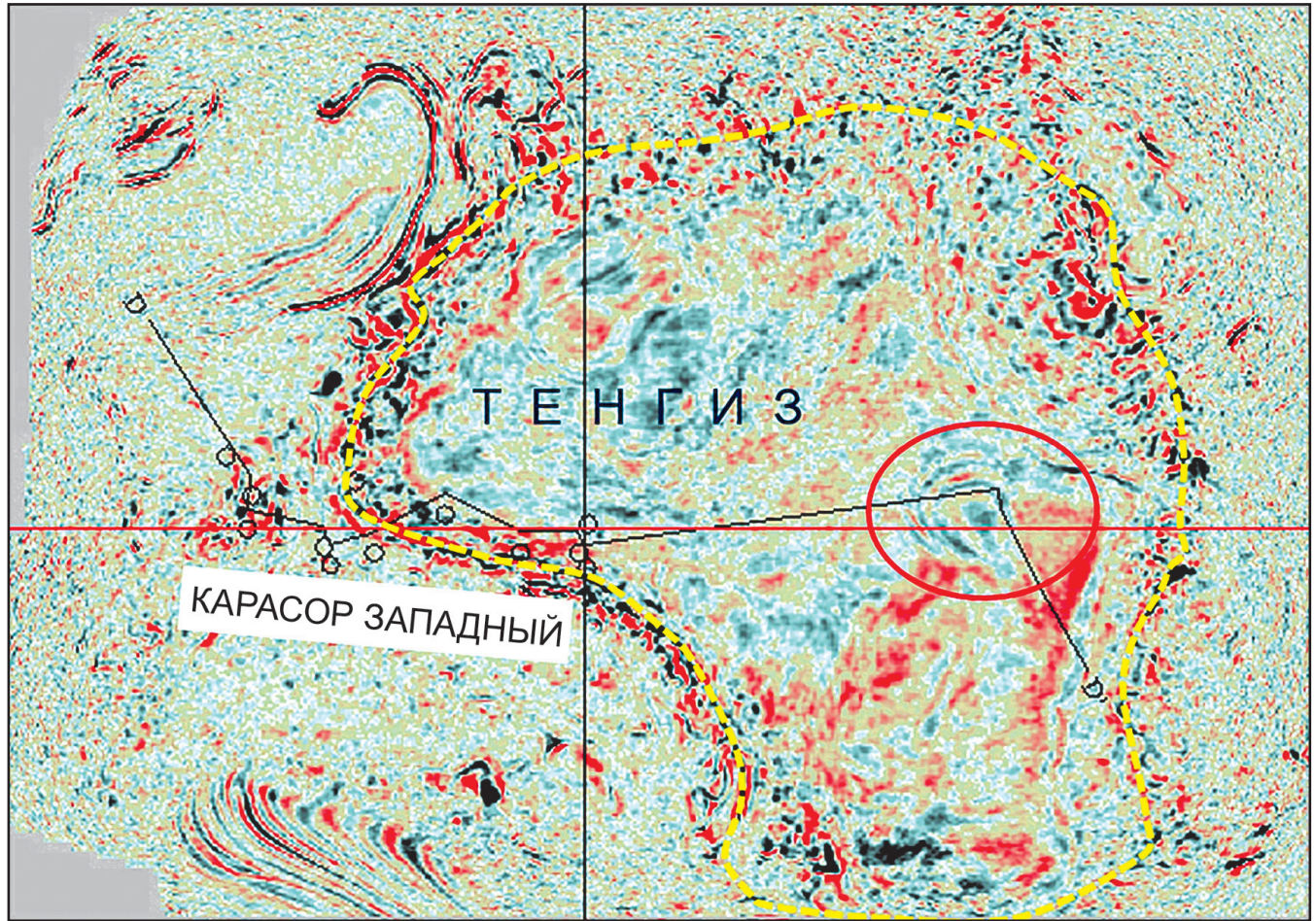

Рисунок 2 - Амплитудный срез по уровню 2500 м сек. Желтый пунктир, контур месторождения Тенгиз. Красная линия - инлайн 2655 (разрез представлен на рисунке 3). Разрез по комбинированной ломаной линии D-D' на рисунке 4.

В круге отражение влияния бессолевого окна в подсолевом комплексе Тенгиза.

Характер отражений от данного горизонта в различных атрибутах приведен на рисунке 5 на фоне структурной карты по его кровле. В атрибутах прослеживается спорадическое распространение ярких амплитуд, приуроченных к отражениям от русловой системы, например, на спектральной декомпозиции. Иными словами, анализ атрибутов по данному горизонту указывает на то, что относительно яркие отражения в этом случае связаны с отражениями от коллекторов русловых систем, а не от насыщения песчаников газом, поскольку в последнем случае их яркость в определенной степени коррелировалась бы со структурным планом, и не полностью смещалась бы на дальнюю периферию структур. 


\section{ГЕОЛОГИЯ}

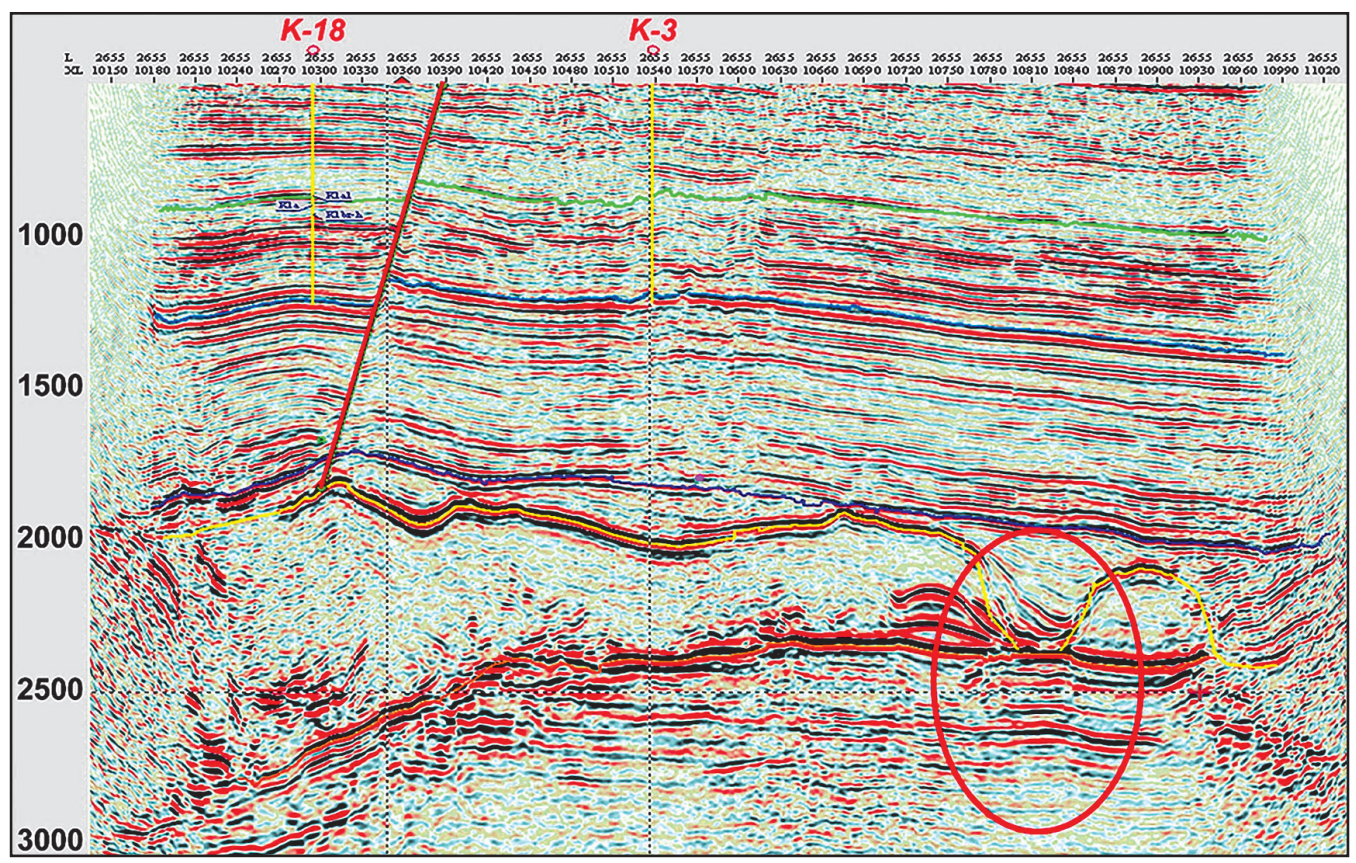

Рисунок 3 - Бессолевая мульда на инлайн 2655 и ее отражение в подсолевой толще

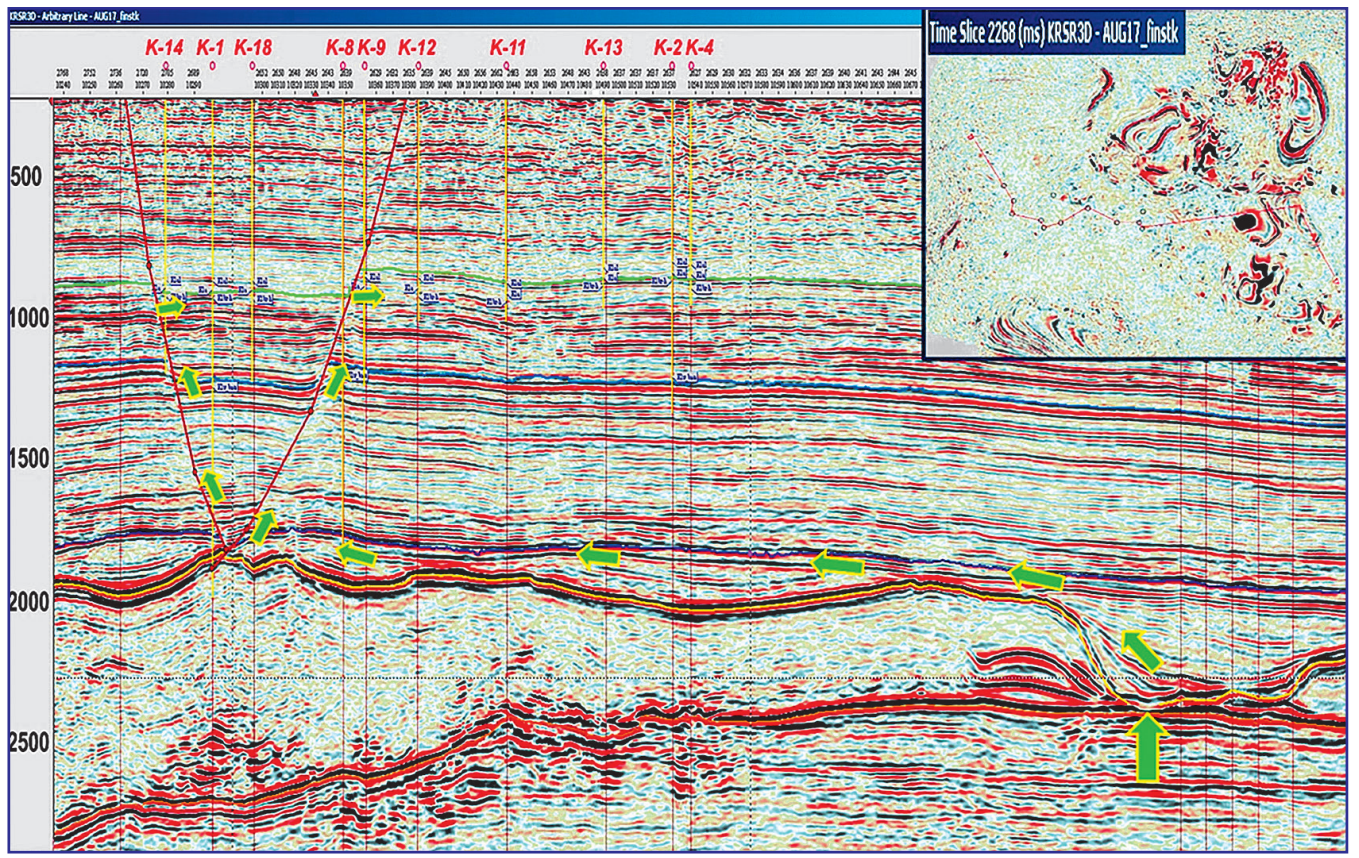

Рисунок 4 - Комбинированный временной разрез, демонстрирующий вероятные пути миграции

УВ от бессолевой мульды к залежам месторождения. На врезке амплитудный срез по уровню 2268 мсек, демонстрирующий распределение мульд в соленосной толще 


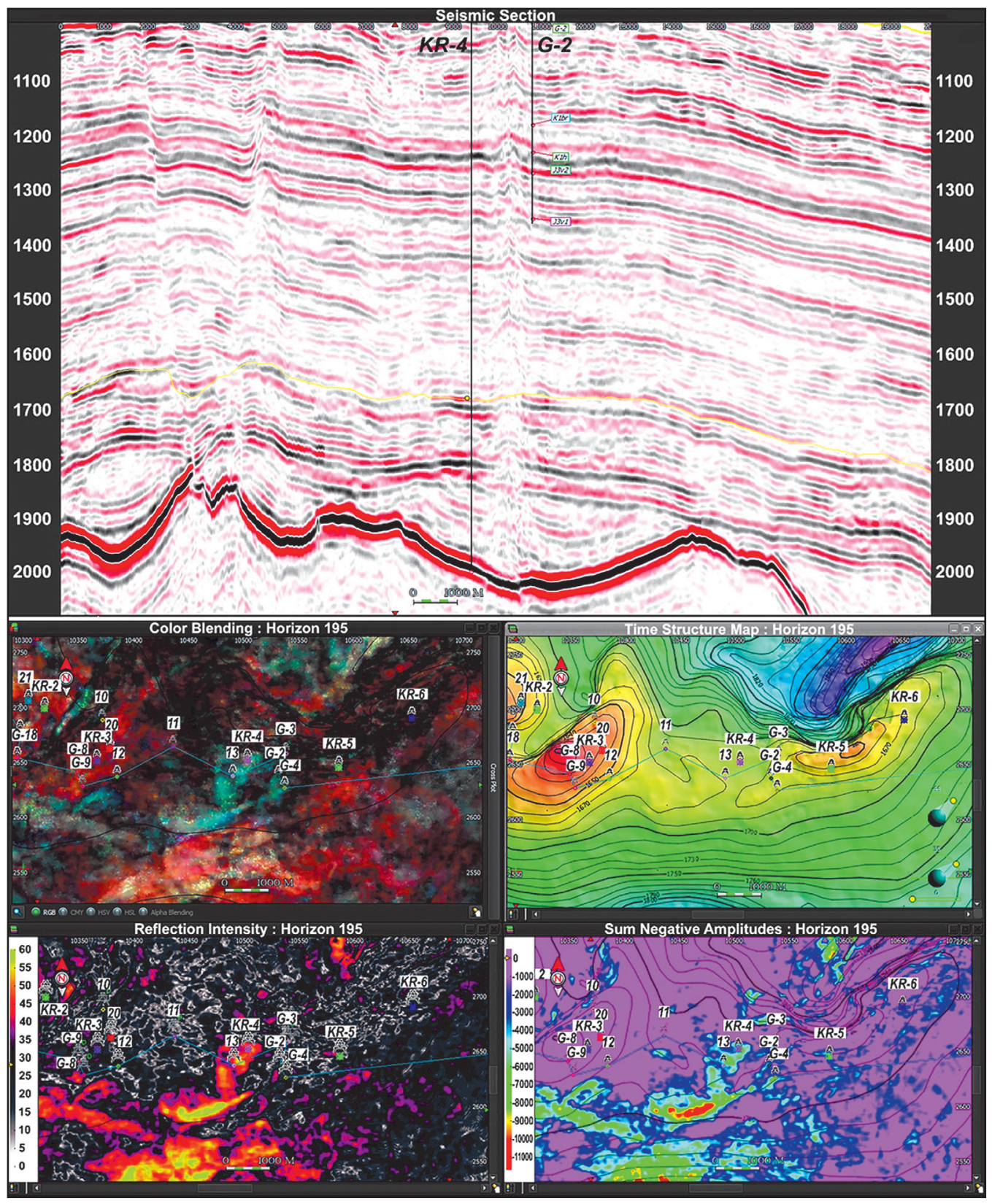

Рисунок 5 - Комбинированный временной разрез, демонстрирующий характер отражений в нижней части надсолевого разреза с прерывистой яркостью отражений (вверху) по линии синего цвета на нижеследующих картах. Атрибуты по горизонту, выделенному на разрезе желтым цветом. Верхний ряд: слева цветовая сумма кубов спектральной декомпозиции (Color Blending); справа - структурная поверхность горизонта (время). Нижний ряд: слева интенсивность отражения (Reflection Intensity); справа - сумма амплитуды сейсмического прогиба (Sum Negative) 
Отсутствие отражений от ловушек, в которых неизбежно должен был накопиться газ, на первый взгляд, не укладывается в принятую концепцию формирования залежей нефти месторождения Карасор Западный. Не трудно подсчитать, что при общих запасах тяжелой нефти месторождения в 7,5 млн т, запасы газа составили бы 3,75 млрд м $^{3}$, а запасы нефти, перешедшей в конденсат - не менее 3,1 млн т. Или в сумме запасы газа и конденсата должны бы составить 6,85 млн т условного топлива (1000 $\mathrm{M}^{3}$ газа $=1$ т нефти). Другими словами, для того чтобы образовалось 7,5 млн т карасорской нефти, необходимо в два раза больше тенгизской нефти, из которой половина должна остаться в виде газоконденсатной системы. И хотя разделение в осадочной толще могло проходит по более сложной схеме с выделением на разных уровнях газа, в разной мере насыщенного жидкими УВ, общий характер оценки это не меняет.

Отсутствие отражений от газа в сейсмических данных может быть объяснено его более высокой подвижностью и миграцией в зону гипергенеза по ослабленным зонам, приуроченным к тектоническим нарушениям. Например, такую зону, немного напоминающую газовый курильщик, можно видеть на рисунке 3, в районе скв. К-3, где вертикальный характер возмущений сейсмики в узком коридоре прослеживается практически от кровли соли.

Подобного характера газовый столб можно видеть и на разрезе на рисунке 5 , разрывающий относительно яркое отражение в нижней части юры. В этом случае в нижних частях разреза могли бы остаться небольшие залежи в разной степени дегазированной нефти.

Подводя итоги проведенному изучению, необходимо отметить, что в надсолевые отложения из месторождения Тенгиз поступило ничтожное количество нефти, если сравнивать с масштабами месторождения, в период, когда сложная его покрышка (нижнепермские глины, ангидрит филипповского горизонта и соль) сработала как аварийный клапан сброса давления, при достижении некоторой предельной величины. С началом разработки для такого явления вообще не может быть места. Нефть подсолевых отложений, попадая в надсолевые, радикально меняет свой состав, обогащаясь более тяжелыми компонентами. Уменьшение количества серы, по-видимому, зависит от длины и характера путей миграции. При основной миграции по нарушению, как в нашем случае, уменьшения серы не произошло, хотя для надсолевой нефти содержание серы, обычно, не превышает половины процента.

Нефть в надсолевом комплексе претерпевает фазовые превращения по мере продвижения в верхние части разреза, вследствие чего выделяющийся из нефти газ отжимает ее в самые верхние ловушки. Залежи газа на путях миграции, скорее всего, были его временными вместилищами и по нарушениям сплошности разреза из-за галокинеза были впоследствии разрушены. До нарушения в нижней части разреза ловушек, по всей видимости, не оказалось и нефтяных залежей, с нефтью Тенгизского типа, в ней не сохранилось. Для дальнейшего изучения этого процесса, особенно характера фазовых переходов по мере перемещения нефти снизу вверх надсолевой толщи, можно было бы использовать результаты изучения характера дегазации тенгизской нефти на установке PVT по мере снижения давления. Если изложенная выше модель миграции нефти верна, то результаты PVT-исследований должны это подтвердить. 


\section{ЛИТЕРАТУРА}

1 Абилхасимов Х.Б. Особенности фрормирования природных резервуаров палеозойских отложений Прикаспийской впадины и оценка перспектив их нефртегазоносности. - М.: ИД «Академия Естествознания», 2016. - 244 c. [Abilkhasimov Kh.B. Osobennosti formirovaniya prirodnych reservuarov paleozojskih otlozhenij Prikaspiyskoj vpadiny i ocenka perspektiv in neftegazonosnosti. - M.: Izdatel'skij dom Akademii Estestvoznaniya, 2016. - 244 s.]

2 Вансинвин Н.3., Мендыбаева К.М., Сагидолла Б.А. Анализ разработки месторождения Тенгиз. Дипломная работа. - Алматы: Институт геологии и нефтегазового дела им. К.Турысова, 2019. - 61с. [Vansinvin N.Z., Mendybaeva K.M., Sagidolla B.A. Analiz razrabotki mestorozhdenija Tengiz. Diplomnaja rabota. - Almaty: Institut geologii I neftegazovogo dela im. K. Turysova, 2019. - $61 \mathrm{s.]}$

3 Воцалевский Э.С. О нефтегазовом потенциале надсолевых отложений юга Прикаспийской впадины // Известия Национальной академии наук Республики Казахстан. - 2006. - №3. - C. 35-42. [Votsalevskiy E.S. O neftegazovom potenciale nadsolevyh otlozhenij yuga Pricaspijskoj vpadiny // Izvestija Nacionalnoj Akademii nauk Respubliki Kazakhstan. - 2006. - №3. - S. 35-42]

4 Марабаев Ж.Н., Жолтаев Г.Ж., Утегалиев С.А. и др. Геологическое строение и перспективы нефтегазоносности Северного и Среднего Каспия. - Астана: «Арт Трибуна», 2005. - 194 c. [Marabaev Zh.N., Zholtaev G.Zh., Utegaliev S.A. at all. Geologicheskoe stroenie I perspektivy neftegazonosnosti Severnogo I Srednego Kaspija. - Astana: «Art Tribuna», 2005. - 194 s.]

5 Сейтхазиев Е.Ш., Утеев Р.Н., Сарсенбеков Н.Д. и др. Геохимический атлас по «фингерпринтингу» нефтти месторождений АО «Эмбамунайгаз» // Вестник нефтегазовой отрасли Казахстана. - 2020. - №2. - С. 61-70. [Seytkhaziev E.Sh., Uteev R.N., Sarsenbekov N.D., et al. Geochimicheskij atlas po "fingerprinting" nefti mestorozhdenij AO "Embamunajgaz" // Vestnik neftegazovoj otrasli Kazakhstana. - 2020. - №2. - S. 61-70]

6 Пунанова С.А., Чахмачев В.А., Агафонова 3.Г., Кукушкина 3.П., Гордадзе Т.И. Геохимия нефти подсолевых отложений западного обрамления Прикаспия // Геология нефти и газа. - 1996. - №7. - С. 27-35. [Punanova S.A., Chakhmachev V.A., Agafonova Z.G., Kukushkina Z.P., Gordadze T.I. Geohimija nefti podsolevyh otlozhenij zapadnogo obramlenija Prikaspija // Geologiya nefti i gaza. - 1996. - №7. - S. 27-35]

7 Матлошинский Н.Г., Адилбеков К. А. Углеводородные системы - основа стратегии успешных поисков месторождений нефти и газа (на примере Прикаспийской впадины) // Нефрть и газ. - 2019. - №4. - C. 32-46. [Matloshinsky N.G., Adilbekov K. A. Uglevodorodnye sistemy - osnova strategii poiskov mestorozhdenij nefti i gaza (na primere Prikaspiyskoj vpadiny) // Neft I Gas. - 2019. - №4. - S. 32-46.]

8 Мурзин Ш.М. Нефтяные системы и история их формирования в акватории Северного Каспия // Вестник Московского университета. Серия 4. Геология. - 2010. - №6. - С. 2335. [Murzin Sh.M. Neftianye sistemy i istorija in formirovanija v akvatorii Severnogo Kaspija // Vestnik Moskovskogo Universiteta. Seriya 4. Geologija. - 2010. - №6. - S. 23-35.]

9 Сейтхазиев Е.Ш. Комплексное геохимическое изучение образцов шлама и керна надсолевых отложений южной части Прикаспийской впадины и корреляция «нефть-нефтематеринская порода» // SOCAR Proceedings. - 2020. - №2. - C. 3049. [Seytkhaziev E.Sh. Kompleksnoe geohimicheskoe izuchenie obraztsov shlama I kerna nadsolevych otlozhenij yuzhnoj chasti Prikaspiyskoj vpadiny I korrelacija "neftneftematerinskaja poroda" // SOCAR Proceedings. - 2020. - №2. - S. 30-49.]

10 Справочник «Месторождения нефти и газа Казахстана» / Под. ред. Абдуллина А.A. Беспаева Х.А., Воцалевского Э.С. и др. - Алматы: ИАЦ, 1996. - 324 с. [Spravochnik «Mestorozhdeniya nefti i gaza Kazakhstana» / Pod red. Abdullina A.A., Bespaeva H.A., Votsalevskogo E.S. at al. - Almaty: IAC, 1996. - 324 s.] 